\title{
PENGARUH MODEL PEMBELAJARAN SIKLUS BELAJAR 5E MENGGUNAKAN MEDIA ANIMASI TERHADAP AKTIVITAS BELAJAR DAN HASIL BELAJAR SISWA SMA KELAS XI PADA MATERI HIDROLISIS GARAM
}

\author{
Muhammad Iqbal $^{1 *}$, Indra Lasmana Tarigan ${ }^{2}$ \\ Program Studi Pendidikan Kimia, Universitas Negeri Padang ${ }^{1}$ \\ Program Studi Kimia, Universitas Jambi ${ }^{2}$ \\ *Email : iqbalrap12@gmail.com
}

\begin{abstract}
Abstrak: Penelitian ini bertujuan untuk mengetahui pengaruh model pembelajaran siklus belajar 5E terhadap hasil dan aktivitas belajar siswa pada materi hidrolisis garam. Rendahnya kemampuan guru dalam menerapkan model pembelajaran yang kreatif, menyebabkan rendahnya hasil dan aktivitas belajar siswa dalam memahami materi-materi kimia, salah satunya materi hidrolisis garam. Hasil penelitian ini menunjukan bahwa hasil belajar dan aktivitas siswa SMA Kelas XI pada materi hidrolisis garam yang diajarkan dengan model pembelajaran sikus belajar 5E menggunakan media animasi lebih tinggi dibandingkan dengan model pembelajaran direct instruction.
\end{abstract}

Kata kunci: Siklus belajar 5E, Animasi, Hasil Belajar Siswa, Aktivitas Belajar Siswa.

\begin{abstract}
This study aimed to determine the effect of the learning cycle 5E model on students' activity and learning outcomes on salt hydrolysis topic. The low ability of teachers to apply a creative learning model causes low learning outcomes and activities of students in understanding chemical materials including salt hydrolysis. The results showed that learning outcomes and activities of students tauhgt by using the learning cycle 5E model with animation media higher than that of the direct instruction model.
\end{abstract}

Keywords: Learning cycle 5E, animation media, learning outcomes, learning activity.

\section{PENDAHULUAN}

Kimia merupakan salah satu cabang IPA yang mempelajari gejala-gejala alam yang berkaitan dengan komposisi, struktur dan sifat, perubahan, dinamika dan energetika zat. Tujuan pembelajaran kimia adalah untuk memperoleh pemahaman perihal berbagai fakta, meningkatkan kemampuan mengenal dan memecahkan masalah, serta meningkatkan keterampilan dalam menggunakan alat-alat dan bahan kimia, serta meningkatkan sikap ilmiah yang diaplikasikan dalam kehidupan sehari-hari (Faizah, 2012). Dalam proses pembelajaran kimia seharusnya siswa dapat mengamati berbagai fenomena kimia secara langsung. Dengan demikian siswa akan mudah memahami konsep- konsep ilmu kimia yang salah satunya adalah hidrolisis garam.

\footnotetext{
*Corresponding author: Program Studi Pendidikan Kimia, Universitas Negeri Padang, Sumatera Barat 26366

Email : iqbalrap12@gmail.com
} 
Hidrolisis garam merupakan salah satu materi ilmu kimia yang dianggap sulit oleh sebagian besar siswa. Berdasarkan penelitian yang dilakukan oleh Haryani, dkk (2014) mengenai identifikasi materi kimia SMA sulit menurut pandangan guru dan calon guru kimia, diperoleh hasil bahwa materi kimia yang dianggap sulit oleh siswa mengenai pandangan guru pada kelas XI salah satunya adalah hidrolisis Garam. Oleh sebab itu dibutuhkan model pembelajaran yang mampu memudahkan siswa dalam memahami materi hidrolisis garam.

Model pembelajaran merupakan kerangka konseptual yang digunakan oleh guru untuk mencapai tujuan pembelajaran. Saat ini proses pembelajaran mengutamakan keaktifan siswa, guru hanya berperan sebagai fasilitator. Oleh karenanya dalam pembelajaran kimia terutama materi hidrolisis garam sebaiknya menggunakan model pembelajaran yang mengarah pada penekanan aktivitas siswa dan pergeseran tanggung jawab kearah siswa, sehingga siswa mampu mengembangkan potensi yang mereka miliki (Budiada, 2011). Akan tetapi berdasarkan pengamatan yang dilakukan selama masa Program Pengalaman Lapangan Terpadu (PPLT) tahun 2016, dalam mengajarkan materi kimia, guru masih jarang melibatkan keaktifan siswa. Interaksi antara guru dengan siswa lebih didominasi oleh guru, sehingga yang terjadi hanyalah proses transfer of knowledge. Dengan demikian diperlukan suatu model yang menjadikan siswa berperan aktif dalam suatu pembelajaran (student centered), sehingga diharapkan akan berpengaruh pada aktivitas dan hasil belajar siswa.

Model siklus belajar-5E adalah model pembelajaran yang terdiri dari fase-fase atau tahap-tahap kegiatan yang diorganisasikan sedemikian rupa sehingga siswa dapat menguasai kompetensikompetensi yang harus dicapai dalam pembelajaran dengan jalan berperan aktif. Model ini terdiri dari lima fase, yaitu: engagement (melibatkan), exploration (mencari data), explanation (menjelaskan), elaboration (mengembangkan konsep), dan evaluation (mengevaluasi). Fase-fase tersebut bertujuan untuk memberikan kesempatan kepada siswa mengkonstruksi pengetahuan dan pengalaman mereka sendiri dengan terlibat secara aktif mempelajari materi secara bermakna dengan bekerja dan berfikir baik secara individu maupun kelompok, sehingga dapat meningkatkan hasil belajar siswa. Hasil penelitian Husna (2012) menunjukkan bahwa siswa yang diajarkan menggunakan model pembelajaran learning cycle-5E memiliki rata-rata nilai hasil belajar lebih tinggi $(x=81,84)$ dibandingkan dengan siswa yang diajarkan menggunakan model pembelajaran ekspositori $(x=67$, 31). Hasil penelitian (Rahayuningsih, 2012) juga menunjukkan bahwa penerapan siklus belajar 5E disertai peta konsep dapat meningkatkan kualitas proses belajar siswa dan hasil belajar siswa. Hal ini membuktikan bahwa model siklus belajar 5E sangat efektif diterapkan dalam pembelajaran kimia terutama pada materi hidrolisis garam Untuk memperoleh hasil belajar yang maksimal, maka model tersebut dapat dilengkapi dengan media pembelajaran.

Media animasi merupakan salah satu media pembelajaran yang sering digunakan oleh guru dalam menjelaskan reaksi- reaksi kimia. Dengan menggunakan media animasi, guru merasa terbantu ketika menjelaskan materi kepada siswa, sehingga memudahkan guru dalam menyampaikan materi pada pembelajaran. Dengan menggunakan media animasi, pembelajaran juga terasa lebih menarik, dan menyebabkan siswa menikmati proses pembelajaran, sehingga dapat meningkatkan hasil belajar siswa. Media animasi yang digunakan pada penelitian ini berupa video audio-visual (Sukiyasa dan Sukoco, 2013). Animasi yang digunakan menampilkan berbagai fenomena tentang materi hirolisis garam, hal ini memudahkan siswa memahami konsep-konsep pada materi hidrolisis garam yang bersifat abstrak. Oleh sebab itu media animasi sangat tepat jika digunakan dalam model pembelajaran learning cycle 5E untuk mempengaruhi aktivitas dan hasil belajar siswa.

Berdasarkan latar belakang yang diuraikan di atas maka peneliti tertarik melakukan penelitian mengenai pengaruh model pembelajaran siklus belajar 5E menggunakan media animasi terhadap aktivitas dan hasil belajar siswa pada materi hidrolisis garam. Tujuan penelitian ini adalah untuk mengetahui pengaruh model pembelajaran siklus belajar 5E menggunakan media animasi terhadap aktivitas dan hasil belajar siswa SMA kelas XI pada materi hidrolisis garam. 


\section{METODE}

Penelitian ini menggunakan rancangan penelitian eksperimen murni (True Eksperimental) yaitu jenis Pretest-posttest control group design. Dalam rancangan penelitian ini terdapat dua kelompok yang terdiri dari kelompok eksperimen dan kelompok kontrol (Arikunto, 2010). Dimana masing- masing kelompok diberikan perlakuan yaitu pada kelompok ekperimen diberikan perlakukan berupa pengajaran dengan menggunakan model pembelajaran siklus belajar 5E menggunakan media animasi dan pada kelompok kontrol diberikan perlakukan berupa pengajaran menggunakan model direct instruction berupa metode cermah dengan menggunakan media animasi. Populasi yang digunakan dalam penelitian ini adalah seluruh siswa kelas XI IPA SMA Negeri 10 Medan tahun ajaran 2016/2017 yang terdiri atas 3 kelas, yaitu XI IPA 1, XI IPA 2, dan XI IPA 3. Untuk memperoleh sampel dengan kemampuan yang sama, maka digunakan teknik purposive sampling. Sehingga, diperoleh sampel siswa Kelas XI IPA 2 yang terdiri dari 40 Siswa sebagai kelas eksperimen dan Kelas XI IPA 1 yang terdiri dari 40 siswa sebagai kelas kontrol.

Teknik pengumpulan data pada penelitian ini terdiri atas metode observasi dan metode tes. Metode observasi dilakukan untuk melihat karakteristik subjek penelitian, dan pada metode tes dilakukan untuk melihat hasil belajar siswa, pada metode observasi digunakan lembar observasi dan metode tes pada penelitian ini menggunakan instrumen tes obyektif berupa soal pilihan ganda dengan masing - masing item terdiri dari lima jawaban (a, b, c, d dan e) dan hanya ada satu jawaban yang paling benar. Soal ini sebelumnya diuji dulu validitasnya dengan menggunakan rumus korelasi produk momen. Tes ini diberikan pada siswa sebelum memulai pembelajaran (pretest) dan setelah melaksanakan pengajaran (posttest) untuk mendapatkan hasil pembelajaran yang telah dilaksanakan.

Teknik analisis data pada penelitian ini terdiri atas uji persyaratan analisis, dan uji hipotesis. Uji persyaratan analisis data dilakukan untuk mengetahui normalitas dan homogenitas data hasil belajar siswa, sebagai syarat penggunaan statistik parametrik. Uji normalitas menggunakan dengan uji chi kuadrat $\left(x^{2}\right)$ data dan uji homogenitas data menggunakan uji $\mathrm{F}$ dengan rumus, kemudian dilakukan uji hipotesis data untuk menguji hipotesis penelitian, pada penelitian ini uji hipotesis yang digunakan berupa uji t pihak kanan.

\section{HASIL PENELITIAN}

\section{Analisis Instrumen Penelitian}

Sebelum instrumen tes digunakan untuk menganalisis hasil belajar siswa, maka dilakukan beberapa analisis instrumen tes, yang terdiri atas:

\section{Validitas Instrumen Tes}

Validitas Instrumen Tes ini merupakan validasi empirik yang bertujuan untuk menganalisis kemampuan instrumen dalam mengukur hasil belajar siswa. Berdasarkan hasil uji validitas dari 40 soal soal yang diuji cobakan diperoleh 30 soal yang valid dan 10 soal yang tidak valid, sehingga yang akan digunakan sebagai instrumen tes dalam penelitian ini adalah 30 soal yang valid.

Tabel 1 Validitas Tes

\begin{tabular}{lll}
\hline No & No. Soal & Keterangan \\
\hline 1 & $1,2,3,5,6,9,10,13,14,15,16,18,20,21,22,23,24,25,27,28,31,32,33,34,35,36,37,38,39,40$ & Valid \\
2 & $4,7,8,11,12,17,19,26,29,30$ & Tidak Valid \\
\hline
\end{tabular}

\section{Tingkat Kesukaran Instrumen Tes}

Analisis tingkat kesukaran instrumen bertujuan untuk menghasilkan instrumen yang baik, yang memiliki tingkat kesukaran ideal, 25\% sulit, $50 \%$ sedang dan 25\% mudah. Pada instrumen test dari 
30 soal valid terdapat 1 soal dikategorikan sukar, 27 soal yang dikategorikan sedang, dan 2 soal yang dikategorikan mudah, sehingga layak digunakan sebagai instrumen tes.

Tabel 2 Tingkat Kesukaran Soal

\begin{tabular}{lll}
\hline $\begin{array}{l}\text { Tingkat } \\
\text { Kesukaran }\end{array}$ & Interval & No. Soal \\
\hline Sukar & $0,00-0,30$ & 36 \\
Sedang & $0,31-0,70$ & $1,2,3,5,6,10,13,14,15,16,18,20,21,22,23,24,25,28,31,32,33,34,35,37,38,39,40$ \\
Mudah & $0,71-1,00$ & 9,27 \\
\hline
\end{tabular}

\section{Daya Pembeda Instrumen Tes}

Daya pembeda instrumen tes bertujuan untuk kemampuan soal untuk dapat membedakan antara siwa yang berkemampuan tinggi dengan siswa yang berkemampuan rendah. Berdasarkan kriteria syarat penerimaan daya beda soal dari 30 soal yang valid diperoleh 7 soal dikategorikan baik, 21 soal dikategorikan cukup, dan 2 soal dikategorikan jelek.

Tabel 3 Daya Beda Soal

\begin{tabular}{lll}
\hline Kriteria & Interval & No. Soal \\
\hline Baik & $0,41-0,70$ & $5,24,28,31,33,35,37$ \\
Cukup & $0,21-0,40$ & $1,2,3,6,10,13,14,15,16,18,20,21,22,23,25,32,34,36,38,39,40$ \\
Jelek & $0,01-0,20$ & 9,27 \\
\hline
\end{tabular}

\section{Reliabilitas Instrumen Tes}

Instrumen yang baik adalah instrumen yang reliable, yang memiliki konsistensi dari serangkaian pengukuran, sehingga perlu dilakukan pengukuran reliabilitas instrumen. Berdasarkan hasil perhitungan reliabilitas tes pada 25 soal valid yang akan digunakan sebagai instrumen penelitian, diperoleh reliabilitas tes ( $r_{\text {hitung }}$ ) sebesar 0,91 dan $r_{\text {tabel }}$ sebesar 0,312 , karena $r_{\text {hitung }}>r_{\text {tabel, }}$, maka soal yang akan digunakan sebagai instrumen tes penelitian ini dinyatakan reliabel.

\section{Deskripsi Data Hasil Penelitian}

Dalam penelitian ini, data hasil penelitian yang diperoleh terdiri atas data skor pretest dan data skor posttest. Skor pretest diperoleh dari hasil test yang diberikan kepada siswa sebelum pembelajaran dimulai yang bertujuan untuk mengetahui kemampuan awal siswa dan untuk menghasilkan sampel penelitian yang berdistribusi normal dan homogen, sedangkan skor posttest diperoleh dari hasil tes yang diberikan kepada siswa setelah seluruh pembelajaran selesai yang juga bertujuan untuk mengetahui hasil belajar siswa. Berdasarkan hasil penelitian diperoleh bahwa hasil belajara siswa yang diajarkan menggunakan model pembelajaran siklus belajar 5E lebih tinggi dibandingkan siswa yang diajarkan menggunakan model pembelajaran direct instruction

\section{Skor Gain Ternormalisasi}

Skor gain ternormalisasi yaitu perbandingan dari skor gain aktual dan skor gain maksimal. Skor gain aktual yaitu skor gain yang diperoleh siswa sedangkan skor gain maksimal yaitu skor gain tertinggi yang mungkin diperoleh siswa, diperoleh data statistik Skor Gain Ternormalisasi pada kelas eksperimen dan kelas kontrol yang dirangkum dalam tabel statistif deskriptif dibawah ini:

Tabel 5 Rangkuman Statistik Deskriptif Skor Gain Ternormalisasi

\begin{tabular}{llll}
\hline Data & Statistik & \multicolumn{2}{c}{ Kelas } \\
\cline { 3 - 4 } Ganin & Rata-rata $(\overline{\mathrm{X}})$ & 0,65 & Kontrol \\
& Standar Deviasi (S) & 0,12 & 0,53 \\
& Varians (S 2$)$ & 0,015 & 0,11 \\
& & 0,011 \\
\hline
\end{tabular}




\section{Uji Persyaratan Analisis}

Sebelum dilakukan uji hipotesis, data-data yang diperoleh harus memenuhi beberapa persyaratan analisis, uji normalitas dan homogenitas. Hasil uji persyaratan ditampilkan dalam tabel 6 dan 7 .

\section{Uji Normalitas}

Pada penelitian ini data yang diperoleh diuji normalitasnya menggunakan uji Chi-Kuadrat, dimana Hasil perhitungan uji normalitas dapat dilihat pada Tabel 4.3 dibawah ini:

Tabel 6 Uji Normalitas

\begin{tabular}{llllll}
\hline Kelas & Data & $\mathrm{X}^{2}$ Hitung & $\mathrm{X}^{2}$ Tabel & $\mathbf{A}$ & Keterangan \\
\hline Eksperimen & Pretest & 3,77 & 11,07 & 0,05 & Distribusi Normal \\
Kontrol & Pretest & 4,28 & 11,07 & 0,05 & Distribusi Normal \\
Eksperimen & Skor Gain & 6,97 & 11,07 & 0,05 & Distribusi Normal \\
Kontrol & Skor Gain & 7,44 & 11,07 & 0,05 & Distribusi Normal \\
\hline
\end{tabular}

$\chi^{2}=$ chi kuadrat; $\alpha=$ taraf signifikan

Pada Tabel 6 diatas menunjukkan bahwa data pada kelas eksperimen dan kelas kontrol memiliki

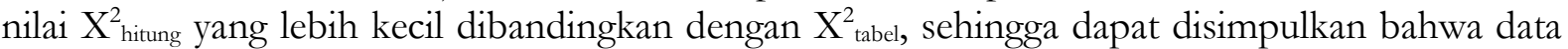
dan skor gain pada kelas eksperimen dan kontrol berdistribusi normal.

\section{Uji Homogenitas}

Pada penelitian ini data yang diperoleh pada kedua kelas sampel yaitu kelas eksperimen dan kelas kontrol diuji homogenitasnya menggunakan uji F. Data hasi perhitungan uji homogenitas dapat dilihat pada tabel 7 berikut:

Tabel 7 Uji Homogenitas

\begin{tabular}{llllll}
\hline Kelas & Data & $\mathrm{S}^{2}$ & $\mathrm{~F}_{\text {hitung }}$ & $\mathbf{F}_{\text {tabel }}$ & Keterangan \\
\hline Eksperimen & Pretest & 4,68 & 1,22 & 1,77 & Data Homogen \\
Kontrol & Pretest & 5,72 & 1,22 & 1,77 & Data Homogen \\
Eksperimen & Skor Gain & 0,015 & 0,73 & 1,77 & Data Homogen \\
Kontrol & Skor Gain & 0,011 & 0,73 & 1,77 & Data Homogen \\
\hline
\end{tabular}

$\mathrm{S}^{2}=$ Varians Sampel; $\mathrm{F}_{\text {tabel }}=\mathrm{dk}(\mathrm{n}-1),(\mathrm{n}-1)(\alpha=0,05)$

Berdasarkan tabel 7 diperoleh harga $\mathrm{F}_{\text {hitung }}$ untuk data pretest dan skor gain pada kedua kelompok sampel masing-masing sebesar 1,22 dan 0,73. Berdasarkan Tabel 7 nilai untuk distribusi F dengan taraf nyata $\alpha=0,05$ untuk $F(0,05)(34,34)$ diperoleh harga $F_{\text {tabel }}$ melalui interpolasi sebesar 1,77. Karena harga $\mathrm{F}_{\text {hitung }}<\mathrm{F}_{\text {tabel, }}$ maka dapat disimpulkan bahwa data pretest dam skor gain pada kelas eksperimen dan kontrol adalah homogen.

\section{Uji Hipotesis}

Uji hipotesis dilakukan untuk mengetahui apakah hipotesis nol (Ho) diterima atau ditolak. Pada penelitian data yang digunakan pada uji hipotesis berasal dari data skor gain dan uji hipotesis dilakukan menggunakan uji statistik jenis uji pihak kanan dengan Kriteria pengujian jika $t_{\text {hitung }}>t_{\text {tabel, }}$, maka hipotesis nihil atau nol ditolak dan hipotesis alternatif diterima. Data hasil uji hipotesis dapat dilihat pada Tabel 4.8 dibawah ini:

Tabel 8 Hasil Uji Hipotesis Pengaruh Hasil Belajar

\begin{tabular}{llccl}
\hline Kelas Eksperimen & Kelas Kontrol & $\mathbf{t}_{\text {hitung }}$ & $\mathbf{t}_{\text {tabel }}$ & Keterangan \\
\hline $\bar{X}=0,65$ & $\bar{X}=0,53$ & & & \\
$\mathrm{n}_{1}=35$ & $\mathrm{n}_{2}=35$ & 4,29 & 1,99 & Ho ditolak, Ha diterima \\
$\mathrm{S}_{1}=0,12$ & $\mathrm{~S}_{2}=0,11$ & & & \\
\hline
\end{tabular}


Berdasarkan tabel 4.8 diperoleh $t_{\text {hitung }}=4,286$ sementara dari data distribusi t diperoleh $\mathrm{t}_{\text {tabel }}$ melalui interpolasi sebesar 1,995. Karena harga $t_{\text {hitung }}>t_{\text {tabel }}(4,286>1,995)$. Dengan demikian Ho ditolak, maka Ha diterima yang berarti "Model pembelajaran siklus belajar 5E menggunakan media animasi lebih baik dari Model Pembelajaran Langsung terhadap hasil belajar siswa SMA kelas XI pada materi hidrolisis garam".

\section{Aktivitas Belajar Siswa}

Dalam penelitian ini juga dilakukan penilaian terhadap aktivitas belajar siswa yang dilihat selama proses pembelajaran berlangsung dari awal sampai akhir pertemuan. Penilaian tersebut dilakukan oleh seorang observer dengan penilaian yang terdiri atas aspek- aspek yang berkaitan dengan aktivitas belajar siswa dan dinilai berdasarkan lembar pengamatan yang terdapat pada rancangan perencanaan pembelajaran. Setiap aspek memiliki indikator dan masing- masing indikator memiliki skor masing- masing dengan skor maksimum tiga dan skor minimum 1. Skor yang telah diperoleh diubah menjadi nilai aktivitas belajar siswa. Berdasarkan hasil perhitungan diperoleh data aktivitas belajar siswa pada kelas ekperimen dan kontol yaitu:

Tabel 9 Aktivitas Belajar Siswa Pertemuan Pertama

\begin{tabular}{|c|c|c|}
\hline Aspek & $\begin{array}{l}\text { Kelas } \quad \text { Ekperimen } \\
\text { (Model Pembelajaran } \\
\text { Learning } \\
\text { Cycle 5E) }\end{array}$ & $\begin{array}{l}\text { Kelas Kontrol (Model } \\
\text { Pembelajaran Direct } \\
\text { Instruction) }\end{array}$ \\
\hline \multicolumn{3}{|c|}{ Aktivitas Belajar Pertemua Kedua } \\
\hline A. Bekerjasama dalam kelompok & $57,14 \%$ & $48,57 \%$ \\
\hline B. Mengemukakan pendapat atau ide & $56,19 \%$ & $53,33 \%$ \\
\hline C. Mengajukan pertanyaan & $60 \%$ & $55,24 \%$ \\
\hline D. Membuat kesimpulan & $61,90 \%$ & $55,24 \%$ \\
\hline \multicolumn{3}{|c|}{ Aktivitas Belajar Pertemua Kedua } \\
\hline A. Bekerjasama dalam kelompok & $71,43 \%$ & $56,19 \%$ \\
\hline B. Mengemukakan pendapat atau ide & $71,43 \%$ & $60 \%$ \\
\hline C. Mengajukan pertanyaan & $72,38 \%$ & $58,10 \%$ \\
\hline D. Membuat kesimpulan & $68,57 \%$ & $59,05 \%$ \\
\hline \multicolumn{3}{|c|}{ Aktivitas Belajar Pertemuan Rata-rata } \\
\hline A. Bekerjasama dalam kelompok & $64,29 \%$ & $52,38 \%$ \\
\hline B. Mengemukakan pendapat atau ide & $63,81 \%$ & $56,67 \%$ \\
\hline C. Mengajukan pertanyaan & $66,19 \%$ & $56,67 \%$ \\
\hline D. Membuat kesimpulan & $65,24 \%$ & $57,14 \%$ \\
\hline
\end{tabular}

Berdasarkan tabel rata-rata aktivitas belajar siswa diatas dapat diperoleh kesimpulan bahwa aktivitas belajar siswa untuk semua aspek pada kelas eksperimen lebih tinggi dibandingkan kelas kontrol. Pembelajaran yang diajarkan menggunakan model pembelajaran direct instruction lebih mengutamakan keaktifan guru dibandingkan keaktifan siswa, oleh karenanya aktivitas siswa rendah. Berdasarkan hasil penelitian ini meunjukkan model pembelajaran siklus belajar 5E menggunakan media animasi efektif untuk meningkatkan aktivitas belajar siswa.

\section{PEMBAHASAN}

Pada penelitian ini yang ingin dilihat adalah pengaruh model pembelajaran siklus belajar 5E terhadap hasil belajar siswa. Berdasarkan hasil analisis data dan pengujian hipotesis yang telah dilakukan, sebagaimana kami sajikan pada tabel 8 bahwa besarnya t-hitung $=4,29$ lebih besar dari $\mathrm{t}$ - tabel $=1,99$ (t-hitung $>\mathrm{t}$-tabel). Hal ini berarti bahwa Model pembelajaran siklus belajar 5E menggunakan media animasi lebih baik dari Model Pembelajaran Langsung terhadap hasil belajar siswa SMA kelas XI pada materi hidrolisis garam. Siswa yang diajarkan menggunakan model pembelajaran siklus belajar 5E menggunakan media animasi memiliki rata- rata skor hasil belajar lebih tinggi daripada siswa yang diajarkan menggunakan model pembelajaran direct instruction 
menggunakan media animasi. Siswa yang diajarkan menggunakan model pembelajaran learning cycle $5 E$ lebih dituntut keaktifannya dalam mengikuti proses pembelajaran. Siswa terlibat langsung dalam menemukan informasi, dan berfikir tentang konsep hidrolisis garam. Oleh karenanya pemahaman siswa akan konsep materi hidrolisis garam semakin baik. Sehingga hasil belajar siswa semakin meningkat. Hal ini sesuai dengan penelitian yang dilakukan (Sari, 2011) mengenai penerapan siklus belajar 5E (Learning Cycle 5E) disertai dengan penilaian portofolio untuk meningkatkan kualitas proses dan hasil belajar pada materi kelarutan dan hasil kali kelarutan kelas XI IPA 2 SMA Negeri 1 Kartsura Tahun Pelajaran 2011/2012 yang menunjukkan bahwa hasil penerapan model pembelajaran siklus belajar 5E disertai peta konsep dapat meningkatkan dan kualitas hasil belajar siswa.

Disamping menganalisis pengaruh siklus belajar 5E terhadap hasil belajar siswa, penelitian ini juga mengukur aktivitas belajar siswa antara model pembelajaran siklus $5 \mathrm{E}$ dengan direct instruction. Berdasarkan hasil pengamatan pada aktivitas belajar siswa (tabel 9) di kelas eksperimen menunjukkan bahwa aktivitas belajar siswa dengan siklus belajar 5-E lebih tinggi dibandingkan pada kelas control (direct instruction) pada setiap aspek keaktifanya, siswa sangat terlibat aktif dalam mengikuti proses pembelajaran. Siswa sangat aktif dalam memahami masalah, mengumpulkan data, dan menyampaikan hasil pemahamannya. Dari penjelasan tersebut dapat disimpulkan bahwa aktivitas belajar siswa yang diajarkan dengan model pembelajaran siklus belajar 5E menggunakan media animasi lebih tinggi dibandingkan dengan aktivitas belajar siswa yang diajarkan dengan model pembelajaran direct instruction menggunakan media animasi. Hal ini sesuai dengan penelitian mengenai penerapan model pembelajaran learning cycle $5 \mathrm{E}$ berbantuan macromedia flash dilengkapi LKS untuk meningkatkan aktivitas dan prestasi belajar siswa pokok bahasan Zat adiktif dan psikotropika kelas VIII SMPN 4 Surakarta Tahun Pelajaran 2011/2012. Menunjukkan bahwa dengan menerapkan model pembelajaran learning cycle $5 \mathrm{E}$ berbantuan macromedia flash dilengkapi LKS, mampu meningkatkan aktivitas dan prestasi belajar siswa. Dengan demikian model pembelajaran siklus belajar 5E sangat tepat untuk digunakan pada proses pembelajaran kimia terutama untuk materi hidrolisis garam.

\section{SIMPULAN DAN SARAN}

\section{Simpulan}

Berdasarkan penelitian dan pengujian hipotesis yang telah dilakukan dapat diambil kesimpulan sebagai berikut:

1. Model pembelajaran learning cycle $5 \mathrm{E}$ menggunakan media animasi lebih baik dari Model pembelajaran direct instruction terhadap hasil belajar siswa SMA kelas XI pada materi hidrolisis garam. Siswa yang diajarkan menggunakan model pembelajaran siklus belajar 5E menggunakan media animasi memiliki rata- rata skor hasil belajar sebesar 19,22, lebih tinggi daripada rata-rata skor hasil belajar siswa yang diajarkan menggunakan model pembelajaran direct instruction menggunakan media animasi dengan skor 17,08.

2. Aktivitas belajar siswa yang diajarkan dengan model pembelajaran learning cycle $5 \mathrm{E}$ menggunakan media animasi sebesar 64,88\%, lebih tinggi dibandingkan dengan aktivitas belajar siswa yang diajarkan dengan model pembelajaran direct instruction menggunakan media animasi yaitu sebesar $55,72 \%$.

\section{Saran}

Berdasarkan hasil penelitian serta kesimpulan yang diperoleh, makapenulis mengajukan beberapa saran sebagai perbaikan di masa mendatang.

1. Guru bidang studi kimia diharapkan dapat menggunakan model pembelajaran siklus belajar 5E dalam pembelajaran kimia di sekolah.

2. Perlu adanya pengembangan lebih lanjut dari media animasi yang digunakan sebagai media pembelajaran sesuai dengan karakterisitik model pembelajaran siklus belajar 5E. Hal ini 
dimaksudkan untukmeningkatkan kualitas materi yang nantinya mengarah kepada kegiatan belajar mengajar yang lebih optimal.

3. Untuk dapat meningkatkan keterampilan guru dalam menerapkan model siklus belajar 5E, sebaiknya guru dapat mengoptimalkan waktu pertemuan, sehingga kualitas pembelajaran meningkat dan berpengaruh baik terhadap hasil belajar siswa.

4. Mengingat hasil penelitian yang masih terbilang sederhana, maka hasil yang diperoleh dari penelitian ini bukan merupakan hasil akhir. Untuk itu, hasil penelitian ini semoga dapat dijadikan referensi untuk pengembangan penelitian selanjutnya.

\section{DAFTAR RUJUKAN}

Arikunto, Suharismi, .2010. Prosedur Penelitian Suatu Pendekatan Praktek, Jakarta: Penerbit Rineka Cipta.

Arikunto, Suharismi, .2006. Prosedur Penelitian Suatu Pendekatan Praktek, Jakarta: Penerbit Rineka Cipta.

Astutik, Sri. 2012. Meningkatkan Hasil Belajar Siswa Dengan Model Siklus Belajar (Learning Cycle 5E) Berbasis Eksperimen pada Pembelajaran Sains di SDN 1 Patrang Jember, Jurnal Pendidikan Sekolah Dasar, 2(1): 143 -153.

Budiada, I Wayan. 2011. Pengaruh Penerapan Model Pembelajaran Inkuiri Terbimbing Berbasis Asesmen Portofolio Terhadap Hasil Belajar Kimia Siswa Kelas X Ditinjau dari Adversity Quotient, Laporan Hasil Penelitian, Undiksa.

Faizah, Nurul, .2011. Upaya Meningkatkan Hasil Belajar Kimia Pada Materi Pokok Laju Reaksi Melalui Penggunaan kombinasi Metode Eksperimen dengan Metode Mindmapping Bervisi Sets Pada Siswa Kelas XI IPA NU 05 Brangsong Tahun Pelajaran 2011/2012, Skripsi, Fakultas Tarbiyah, Institut Agama Islam Negeri Walisongo, Semarang.

Haryani, Sri, dkk. Identifikasi Materi Kimia SMA Sulit Menurut Pandangan Guru dan Calon Guru, Prosiding September 2014.

Husna, Saifatul, dkk. 2012., Pengaruh Model Pembelajaran Learning Cycle 5E Pada Materi Hidrokarbon Terhadap Hasil Belajar Siswa Kelas XI SMK Negeri 2 Batu Program Keahlian Agribisnis Hasil Pertanian. Laporan Hasil Penelitian. FMIPA Universitas Negeri Malang.

Made, Wena, 2009, Strategi Pembelajaran Inovatif Kontemporer: Suatu Tinjauan Konseptual Operasional, Jakarta: PT. Bumi Aksara.

Purwanto, Ngalim, 1984, Psikologi Pendidikan, Bandung: Remdja Karya.

Sari, Sandi D C, dkk. 2013. Penerapan Siklus Belajar 5E (Learning Cycle 5E) Dengan Penilaian Portofolio Untuk Meningkatkan Kualitas Proses dan Hasil Belajar Pada Materi Kelarutan dan Hasil Kali Kelarutan Siswa Kelas XI IPA 2 SMA Negeri 1 Kartasura Tahun Pelajaran 2011/2012. Jurnal Pendidikan Kimia. 1(2): 1.

Silitonga, P.M., 2011, Statistik teori dan Aplikasi dalam Penelitian, Medan: FMIPA UNIMED, Medan. Sofyan, Ahmad, dkk., 2006, Evaluasi Pembelajaran IP A Berbasis Kompetensi, Jakarta: UIN Press.

Sudarmo, Unggul, 2013, KIMIA untuk SMA/ MA Kelas XI, Jakarta: Erlangga.

Sudjana, Nana, 2009, Penilaian Hasil Proses Belajar Mengajar, Bandung: PT Remaja Rosdakarya.

Sukiyasa, Kadek \& Sukoco. 2013. Pengaruh Media Animasi Terhadap Hasil Belajar dan Motivasi Belajar Siswa Materi Sistem Kelistrikan Otomotif, Jurnal Pendidikan Vokasi, 3.

Sukmadinata, Nana Syaodih, 2009, Landasan Psikologis Proses Pendidikan, Bandung: PT. Remaja Rosdakarya.

Sulistyowati, Tri, dkk. 2014. Implementasi Learning Cycle 5E Dilengkapi Worksheet Untuk Meningkatkan Kreativitas dan Prestasi Belajar Siswa Pada Materi Pokok Hidrolisis Garam Kelas XI IPA 1 Semester Genap SMA Negeri 3 Boyolali Tahun Pelajaran 2013/2014. Jurnal Pendidikan Kimia, 4(3): 1. 